\title{
Physiological adaptability of livestock to heat stress: an updated review
}

\author{
Veettiparambil Pandarathil Rashamol - Veerasamy Sejian - Madiajagan Bagath •
}

Govindan Krishnan - Payyanakkal Ravindranathan Archana - Raghavendra Bhatta

VP Rashamol - V Sejian (Corresponding author) - M Bagath

email: drsejian@gmail.com

- G Krishnan - PR Archana - R Bhatta

ICAR-National Institute of Animal Nutrition and Physiology, Adugodi, Bangalore-560030, India.

Received: March 17, 2018 - Accepted: April 17, 2018

\begin{abstract}
Climate change associated heat stress was established to be the crucial factor, which negatively influences animal production. The animals possess several adaptive mechanisms which are helpful for their survival in harsh environmental conditions, but while doing so their productive performances are compromised. Among the various mechanisms, which helps to maintain homeostasis in animals, Physiological adaptability was considered one of the primary response mechanisms by which the heat stressed animals survive the heat stress. This review is therefore an attempt to provide the audience an updated review on the subject to signify the importance of physiological responses in animals and their role in surviving the stressful environment. Respiration rate (RR), pulse rate (PR), rectal temperature (RT), sweating rate (SR) and skin temperature (ST) are the cardinal physiological variables which helps to maintain the heat balance and homeostasis in the stressed animals. Among the various physiological variables, RR, RT and ST were established to be ideal indicators for quantifying heat stress in several farm animals. Therefore, these variables can be effectively used to assess the severity of heat stress in livestock. Although these variables are considered significant in establishing the heat stress impact in animals, a wide genetic variation was also established in these response mechanisms. Further, variations in physiological adaptability were also established between indigenous, cross bred and pure bred animals. The indigenous livestock breeds were tipped to be exhibiting less physiological variability as compared to their counterparts. These discussions vividly indicate the importance of studying in detail the physiological adaptive mechanisms in different farm animals and these efforts can help the farming community to identify the suitable agroclimatic zone specific livestock breeds which can go in long way to help to ensure climate resilient livestock production.
\end{abstract}

Keywords: adaptation, climate change, heat stress, respiration rate, rectal temperature, skin temperature

\section{Introduction}

Climate change is the most challenging issue human kind had ever experienced which pose risks to both the global ecological balance as well as economic security. Rising global earth surface temperature is one of the most intriguing factors emerging from the changing climate. According to the fifth IPCC Assessment report (AR5), by the end of 2100 global surface temperature is expected to rise by $1-7^{\circ} \mathrm{C}$ (IPCC 2013). The rising earth surface temperature along with the increased intensity of weather and climatic extremities ultimately has its effects on the global food security.

Livestock is an important agricultural enterprise which is a major contributor to the global food security. Globally, about $17 \%$ of the kilocalorie consumption and $33 \%$ of the protein consumption is contributed from the various livestock commodities (Rosegrant et al 2009). According to FAO (2015), the global demand for livestock products are expected to double by 2050 due to the improved standard of living and the rising population. Climate change emerged as one of the main threats to the livestock sector (Nardone et al 2010). Further, the climate change induced heat stress has established as one of the crucial factors affecting livestock production. Heat stress may decrease milk production and quality, meat production, reproductive efficiency and animal health (Sejian et al 2016). Dairy and beef industry are especially affected by heat stress in monetary terms (Nardone et al 2010).

Adaptation to prolonged heat stress may lead to production losses (Sejian et al 2010). In order to maintain the body temperature in heat stressed animal, they initiate compensatory and adaptive mechanisms like behavioural and physiological changes to re-establish homeothermy and homeostasis which promote welfare and favour survival in a specific environment (Indu et al 2015).

All animals possess a thermal comfort zone, within which their physiological functions would be beneficial. During day time, the livestock animals maintain their body temperature in the range of $\pm 0.5{ }^{\circ} \mathrm{C}$ (Henry et al 2012). 
Further, the temperature exceeds the upper critical level, the animal is said to be in heat stress condition. For a single source of stress such as heat stress, animals develop a phenotypic response called acclimation. Acclimation results in increased water in-take reduced feed intake and altered physiological functions such as productive and reproductive efficiency, changes in respiration rate and pulse rate.

Environmental factors, animal factors and thermoregulation play important role in energy exchange between environment and the animal. Environmental factors include ambient temperature, relative humidity, solar radiation and wind speed. Further, animal factors comprise breed, colour, stage of lactation and health status. Finally, thermoregulatory mechanisms include circulatory adjustments, sweating and panting.

Heat stressed animals, physiological adaptation is composed of two components: 1) heat load due to metabolism, heat exchange, radiation, and convection with the environment; 2) heat dissipation that is loss of heat loaded through sweat evaporation (Indu et al 2015). Some of the physiological determinants of adaptations to heat stress are rectal temperature (RT), pulse rate (PR), respiratory rate (RR), that may result in reduction of productive potential in animals (Indu et al 2015).

The main emphasizes of this review article is to provide updated information on physiological adaptability of livestock to heat stress.

\section{Climate change and livestock production}

Global climate change is mainly instigated by greenhouse gas (GHG) emissions that result in warming of the atmosphere (IPCC 2013). According to the perspective of IPCC, the changing climate could lead to several environmental problems like drought, floods and health hazards etc. Likewise, it is also estimated that the average earth's temperature may rise by $1.4^{\circ} \mathrm{C}-5.8^{\circ} \mathrm{C}$ at the end of 2100 (IPCC 2007). This projection is expected to adversely affect the agriculture sector in the coming years.

Climate change is the most intriguing factor that threatens the survival of livestock. The change in climatic variables such as temperature, humidity, and radiation are the most serious factors that affect the growth and production ability of livestock (Thornton 2010). Further, the significant changes in climate may negatively affect the quantity and quality of feed available for livestock and also enhances the competition for the existing natural resources (Garnett 2009). In addition, increased temperature and rainfall pattern as a result of climate change may also cause sudden outbreak of several new diseases in livestock.

Ambient temperature, photoperiod, and rainfall are the different direct impacts of climate change. Moreover, indirect impacts include disease occurrence, less feed and water and low grazing land available. Further, both the direct and indirect impacts of climate change are expected to have several adverse impacts on livestock which hampers their productivity. These potential environmental stressors distress health, growth, yield and reproductive functions of livestock (Nienaber and Hahn 2007; Svotwa et al 2007; Nwosu and Ogbu 2011). Apart from affecting their production, the various environmental stresses that arise due to climate change may also impart enormous strain in the physiological ability of these animals to cope up to the existing stressful conditions (IFDA 2009). Among all the climatic variables, environmental temperature seems to have a critical role that negatively influencing livestock production (Reynolds et al 2010).

\section{Heat stress influencing livestock production}

Livestock systems occupy about one-third of the global ice-free terrestrial land surface (Steinfeld et al 2006). Agriculture sector contribute about 53 per cent of gross (GDP) and is quickly growing (World Bank 2009). Presently, one of the fast-growing sectors in developing countries is livestock. Globally, the livestock sector directly supports 600 million poor smallholder farmers in the developing world as well as it progressively provides employment for at least 1.3 billion people (Thornton et al 2010). In addition, livestock sector has significant role in global food supply. Also, they provide various benefits including clothing, fuel, nutrient cycling for soils, draught, income and significant role in future food and income insurance against climate and weather-associated risk (Henry et al 2012).

UNPD (2008) estimated that the world human population reach up to 9.15 billion by the end of 2050. Along with the growing population, increased income and urbanization in developing countries result in rapid increase in the demand for livestock products (Delgado et al 2005). In sub-Saharan Africa and South Asia, the livestock product demands nearly double (200 kcal per person per day in 2000 to around $400 \mathrm{kcal}$ per person per day in 2050) (Van Vuuren et al 2009). In developing world, the total meat production is tripled from 45 to 134 million tons between 1980 and 2020 (World Bank 2009). Livestock products are the best providers of nutrients and traction for growing crops in smallholder system have a vital role in risk reduction for vulnerable communities (Thornton et al 2010). The growing demands for livestock products provide opportunity to livestock keeper in the developing countries and mainly the demands are met by the local farmers (Thornton et al 2010).

Climate change could have a significant impact on the economic viability of livestock production (Henry et al 2012). As the climate continues to warm, the extreme heat events like hotter days and nights, heat waves etc are expected to worsen the severity, duration, and frequency (IPCC 2007). The 
observed changing climates, particularly increased temperature, have already affected the biological system globally. This results in changes in species distribution, population sizes, timing of reproduction, migration events, and increase in the frequency of pest and disease outbreak, especially in forest ecosystem (Henry et al 2012). Climate and location are undoubtedly the most significant factor influencing livestock production. In fact, climatic variables such as ambient temperature and rainfall patterns have an important role in the availability of pasture and food resources throughout the year (Elsa Lamy et al 2012). These mainly affect nutrient availability of livestock and make alteration in the animal performance (Smit et al 1996). Further, this also may lead to rapid spread of existing vector-borne disease and macro-parasites, accompanied by the emergence and circulation of new diseases. During heat stress condition, higher circulation of prolactin may modulate various mechanisms for dissipation of heat to support homeothermy, it can be used as an indicator of heat stress (Alamer et al 2011). Heat stress has negative impact on reproductive function of livestock. Moreover, high temperature and relative humidity alter the cellular function and impairs various tissues or organs of the reproductive system (Amundson et al., 2006; Sprott et al 2001). In addition, the exposed of female animals to high temperature and humidity, may effects the follicular growth to ovulation suppresses, combined by declined LH receptor level and follicular estradiol synthesis activity. Further, in male, fertility is more significant for fertilization of oocyte to produce a good, viable and genetically potential sperms. It is well known that, the male testes must be cooler than the core body temperature for the production of sperm. Consequently, increased testicular temperature leads to infertility in male (Bhakat et al 2014).

According to Reynolds et al (2010), rise in temperature may strongly affect the production, health, and reproductive performance of livestock. As a result of increased temperature, the normal behavioural, immunological, and physiological functions of animals are affected (Nienaber and Hahn et al 2007). Heat stress also affects the metabolic and digestive functions due to altered or impaired feeding activity (Mader et al 2003). Further, the adverse impact of heat stress on livestock production is general functional change livestock brings, in an effect to deviate its energy to support the adaptation mechanisms without compromising the vital body functions.

\section{Significance of physiological adaptability in livestock}

The animals possess various adaptive mechanisms to cope with the changing climatic conditions (Alameen et al 2012). The adaptive capability of the animals are determined by morphological, anatomical, physiological, biochemical and behavioural characteristics of these animals which helps them to survive in a specific environment (Das et al 2016). Resilience is one of several measures of sustainability. Resilience is referred as the extend of change a system can undergo and still retaining the same structure while maintaining options to develop (Walker et al 2002). The concepts of resilience include resistance, connectedness, vulnerability and adaptability.

The animal shows several physiological adaptation mechanisms to cope up the adverse climate condition. Some of the physiological determinants of adaptations to heat stress are respiration rate (RR), rectal temperature (RT), pulse rate (PR), skin temperature (ST) and sweating rate (SR) (Indu et al 2015). Respiration rate is one of the ideal biomarkers of heat stress. The animals bring in respiratory evaporative cooling mechanisms through the process of multifold increase in RR (Indu et al 2015). In homeostasis, PR reflects the circulation and metabolic status. Ambient temperature, humidity, season and day timings may influence the cardio respiratory system (Marai et al 2007). Animal core body temperature is represented using rectal temperature (Nieslon 2002). The cutaneous evaporative cooling mechanisms are brought through increased sweating rate. Further, every species has its own TNZ and the animal exposed to high temperature may rise their body temperature from the TNZ. In addition, the animals are very sensitive to the upper critical temperature (UCT) and it has been established that even $1{ }^{\circ} \mathrm{C}$ rise in temperature from the UCT can bring down the production of livestock species. (McManus et al 2009). Thus, the physiological traits help the animals to adjust with the extreme climatic condition. However, while doing so the productive potential are compromised in most species in order to maintain regular energy supply for vital physiological functions (Aleena et al 2016).

\section{Physiological responses in livestock}

Physiological adaptability is the modifications in the behavioural or metabolic response in animals to cope with the extreme environmental conditions. The exposure of animal to high quantum of heat stress induces an increase in the dissipation of excess body heat to the environment to negate heat load in their body (Al-Haidary et al 2012). Further, dissipation of excess body heat is brought by the physiological responses including RR, RT, PR, ST, and SR (Sharma et al 2013). In addition, the environmental variables alter drastically in a day, consequently physiological responses also strongly affected by the time of a day. Moreover, physiological responses generally increase from the morning (07:00 a.m.- 10:00 a.m.) till noon (11:00 a.m.- 02:00 p.m.). However, from evening till night time these responses begin to drop (11:00 p.m.- 06:00 a.m.), and values of the physiological variables remains stable during this period (da 
Silva et al 2017). Fig.1 describes the variation in the physiological responses during heat stress condition in cattle.

Respiration rate

Respiration is the intake of oxygen $\left(\mathrm{O}_{2}\right)$ and elimination of carbon dioxide $\left(\mathrm{CO}_{2}\right)$ under thermo- neutral condition which leads to evaporation and dissipation of moisture from the respiratory tract to maintain thermal balance. Therefore, this mechanisms are very crucial in preventing the hypothermia which otherwise occur under heat stress conditions (da Silva et al 2017). The RR is visually determined by counting flank movements per minute using stopwatch without disturbing the animal (Shaji et al 2016).

The RR may act as an early warning signal of heat stress condition in livestock. Further, marked increases in the RR from the normal level indicate the animals are trying to maintain homeostasis by dissipating heat load from their body (Nienaber et al 2007). Higher RR is observed in cattle exposed to increased ambient temperature and relative humidity (Upadhyay et al 2009). The increased RR of animal during heat stress condition is an attempt to upsurge the respiratory evaporative cooling mechanisms by dissipating body heat. In a comparative study, the RR were $15.738 \pm 0.795$, $18.158 \pm 0.795$ and $29.818 \pm 0.795$ in Sahiwal and $15.779 \pm 1.136,22.979 \pm 1.136$ and $47.299 \pm 1.136$ in Karan Fries cattle during winter, spring and summer seasons respectively. This pattern of $R R$ revealed that, with increase in THI there was increased RR in both Sahiwal and Karan Fries cattle (Sailo et al 2017). This shows the irrespective of breeds the animals relies heavily on the respiration rate to maintain body temperature during exposure to different environmental temperature. In a recent study, Valente et al (2015) also reported significantly higher $\mathrm{RR}$ in angus cattle (104 breaths/minute; $37.7^{\circ} \mathrm{C}$ ) during heat stress condition. Further, according to Kumar et al (2016) dissipation of the extra heat load by respiratory cooling mechanism vaporizing more moisture to the environment. Further, rapid increase in the RR indicates the greater susceptibility of animals to heat stress condition. Moreover, the temperature above the threshold environmental condition the body temperature begins to rise indicating the animal's inability to dissipate the extra heat load through respiratory evaporating cooling mechanism. This increased body temperature above the threshold environmental temperature is usually accompanied by reduced feed intake resulting in reduced performance and poor health status. In addition, the prolonged exposure to such extreme environmental condition may question the survivability of the animal (Berman et al 2005). Above discussion clearly indicates that RR could be considered as the practical and reliable measure of heat load and the RR higher than 80 breath/minute was found to be an indicator of high quantum of heat stress in farm animals (Indu et al 2015).

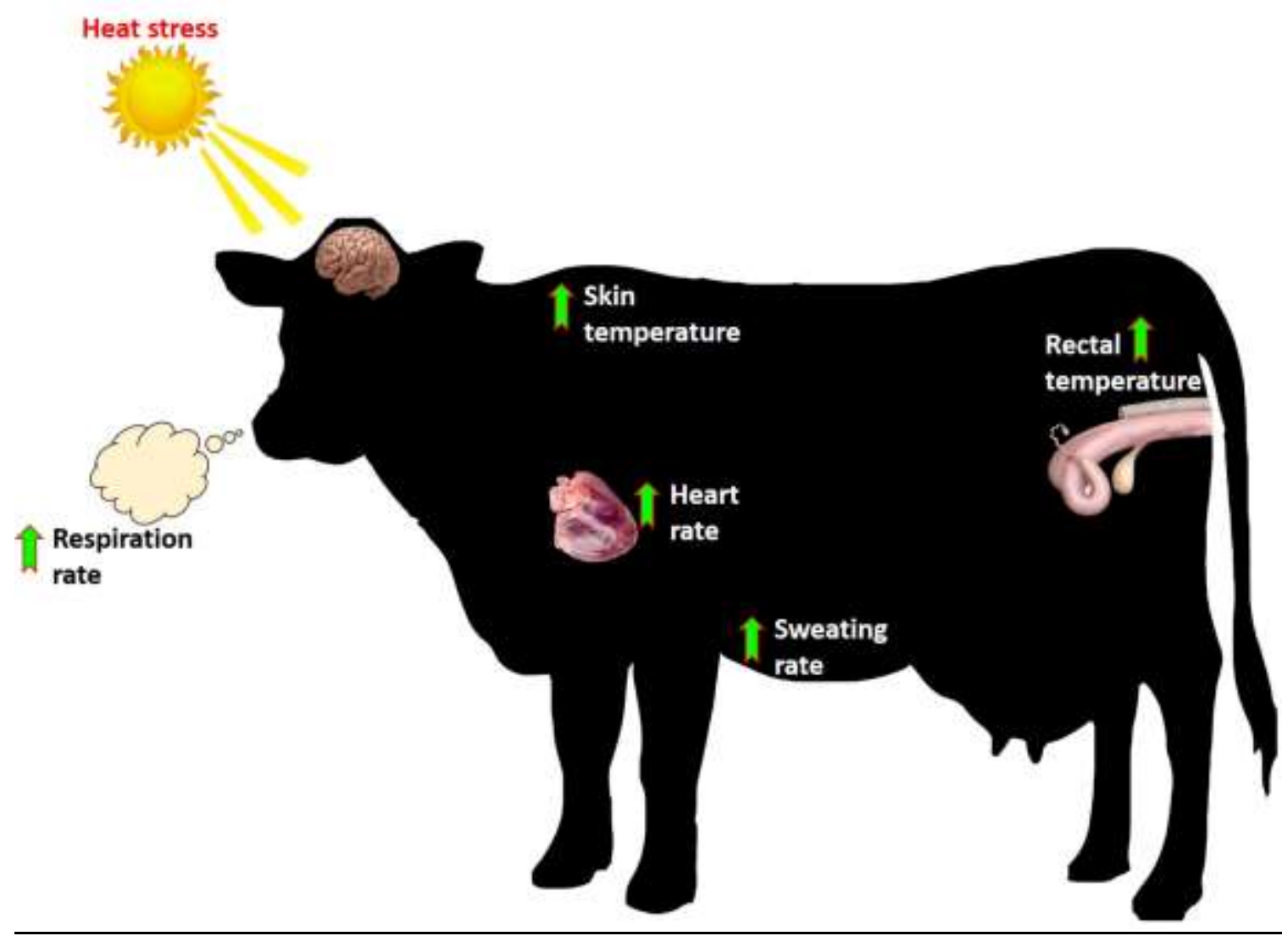

Figure 1 Alterations in various physiological variables in heat stressed cattle. 


\section{Rectal temperature}

Rectal temperature is recognized as the ideal indicator for heat load in animal's body as well as it is considered as an important measure of physiological status (Koga et al 2004). Exposures of animal to high quantum of heat stress try to balance their body temperature by dissipating heat load as much as possible. If all these mechanisms fail to maintain body temperature leads to increases in RT (Marai and Haeeb 2010). The RT was recorded using a clinical thermometer by inserting the thermometer by $6-7 \mathrm{~cm}$ inside the rectum inclined towards the wall of the rectum. The RT is used as a representative measure of animal's core body temperature. Further, rising RT represents the failure of thermo-regulatory mechanism in animals' body. According to Kadzere et al (2002), rising RT even $1{ }^{\circ} \mathrm{C}$ or less is enough to reduce the performance in livestock. Moreover, RT is related with many physiological traits associated with heat stress in farm animals (McManus et al 2009). According to Salio et al (2017), the RT also show similar trend like RR. In Sahiwal RT $\left({ }^{\circ} \mathrm{C}\right)$ were $37.300 \pm 0.095,38.178 \pm 0.095$ and $38.810 \pm 0.095$, while in Karan Fries $37.492 \pm 0.115,38.398 \pm 0.115$ and $39.186 \pm 0.115$ during winter, spring and summer respectively. These results reveal that with increases in THI there was increased RT in both Sahiwal and Karan Fries breeds. Further, Chandra Bhan et al (2013) also reported direct correlation between RT, humidity and other physiological traits in Murrah buffaloes and Karan-Fries cattle. Several other studies conducted in different livestock (Koubkova et al 2002; Chakravarthi et al 2004; Singh and Singh 2005; Chandra Bhan et al 2012) also reported the similar observation of increases in rectal temperature in animals exposed to high quantum of heat stress. These findings indicate that RT may be considered another reliable biological marker for quantifying heat stress response in domestic livestock.

Pulse rate

The PR reflects primarily the homeostasis of circulation along with the general metabolic status (Sejian et al 2010). The cardio respiratory system is influenced by season, day timings, ambient temperature, humidity and exercise (Marai et al 2007). The PR was measured by palpating the femoral artery of animal. Further, the exposure of animal to high ambient temperature generally increases the PR. Moreover, PR is affected by heat stress and therefore this physiological parameter to may act as reliable indicator of livestock in harsh environmental condition (Das et al 2011). Further, Shaji et al (2016) also reported significantly highest PR in heat stressed Osmanabadi goats indicating its role to assessing the quantum of heat stress in these animals.

Heart rate (HR) is expected to vary seasonally because the metabolic rate and the amount of food consumption vary with season (Indu et al 2015). Heat to be lost sensibly (loss by conduction, convention and radiation) and insensibly (loss by diffusion water from the skin) by increased blood flow from the core to the surface (Gupta et al 2013; Hooda and Upadhyay 2014). Further, the exposure of animal to heat stress induces circadian rhythmic changes in the heart of the animal. Alhaidary (2004) report that the daily average HR reduced during heat stress condition with 115.7 and $85.8 \pm 11$ beat /min for the control and heat stress groups, respectively. In addition, HR was reported to increase during the peak hour of the heat load (15:00) in cattle. Further, Popoola et al (2014) also established a correlation between HR and metabolic heat production.

\section{Skin temperature}

In mammal, skin is the important pathway for heat exchange between the body and the surrounding environment. The ST was measured in different parts of body (back, flank and forehead) using a skin surface thermocouple probe connected to a microprocessor-based handheld thermometer (Paulo and Lopes 2014). The ST of an animal varies based on the quantum of sun rays to which the different body parts are exposed. Further, ST is the result of skin blood flow, that ends with regulation of heat between body core and the skin (Marai 2007). Moreover, the accelerated ST indicate the increased blood flow to the skin from the body core with cutaneous vasodilation to enhance the heat exchange between skin and the surrounding environment (Collin et al 2002). The higher ST can be attributed partially to the fact that exposure to heat stress alter the blood flow, redistribution of blood flow and increase blood flow to the skin surfaces. The ST recorded to be highest during summer season. During the day, the ST was lower at 8:00 $\mathrm{h}$ than at 12:00 $\mathrm{h}$ and 16:00 $\mathrm{h}$ during summer (Marai et al 2000). The ST increased by $0.22{ }^{\circ} \mathrm{C}$ in animals per extra degree of ambient temperature exposure (Paulo and Lopes 2014). Similar result was also reported by Renaudeau et al (2007) in pig with $0.22{ }^{\circ} \mathrm{C}$ per degree of ambient temperature.

\section{Sweating rate}

The thermoregulatory mechanisms including circulatory adjustment, sweating and panting have significant influence in heat exchange between the animal and the surrounding environment. Evaporation is the most important for heat dissipation in animal body. Dissipation of excess heat from the body through cutaneous evaporative cooling mechanisms is known as sweating (Gebremedhin et al 2008). Evaporative cooling is the dominant mechanism seen in dairy cattle for heat loss when they are exposed to high temperature (Gebremedhin and Wu 2001). Sweating is one of the effective mechanisms in animals considered sweating species for 
excreting excessive heat from body. Sweating is influenced by weather parameters such as wind velocity, air temperature, relative humidity, and thermal and solar radiation. Whereas other factors that affect the efficacy of evaporative cooling from the skin surface are fur or hair coat physical and optical properties, density and thickness of hair coat, hair length and both hair and skin colour (Gebremedhin et al 2008). Hillman et al (2001) conducted experiment on dairy cows and reported higher sweating rate in black cows $\left(800 \mathrm{~W} / \mathrm{m}^{2}\right)$ than white cows $\left(500 \mathrm{~W} / \mathrm{m}^{2}\right)$. da Silva et al (2003) further established that light hair coats exhibited higher reflectivity than dark hair coats having wavelengths ranging from 300 to $850 \mathrm{~nm}$. Further, increased relative humidity reduced evaporative heat loss from the skin surface because of the lower water vapor concentration gradient between the skin surface and ambient air (Jiang et al 2005). Another study conducted on heifer exhibited an increase in sensible heat flux under sunlight in the order of $26 \%$ for dark-red, $22 \%$ for black, $5 \%$ for tan, and $4 \%$ for white coat color (Hillman et al 2005). Finally, this study also concluded that the heat gain was profoundly higher for heifers with dark (Black Angus) and dark red (MARC III) hair coats than those with white and tan hair coats (Hillman et al 2005). Evaporative cooling mechanism lead to defecate a lot of body electrolytes such as potassium and this causes acidbase imbalance in body.

\section{Breed differences in physiological adaptability in livestock}

Among the livestock species goat was considered to be the most adaptive species due to their higher ability to produce, survive and reproduce in the climate changing scenario (Silanikove and Koluman 2015). Furthermore, goats can tolerate severe heat stress and less water and feed periods, which make them adaptable to any climatic condition, compared to other livestock species such as cattle, sheep and buffalo (Aziz 2010). The adaptive capacity of the livestock species varies between the breeds and this difference was determined by the quantum of heat stress and the duration of such exposure. Indigenous breeds have higher thermo-tolerant capacity as compared to the cross bred and pure bred animals. Genetic differences were established in physiological adaptive capabilities of different breeds of goats (Souza et al 2014). Table 1 describes the breed differences in physiological variables of heat stressed ruminant livestock.

In a recent study by Pragna et al (2017) identified Salem Black goat breed to be better breed to adapt to heat stress as compared to both Malabari and Osmanabadi goats. Further, increased RR in both Sirohi and Jhakrana breeds of goat as compared to Barbari goat bread and higher RT reported in Barbari goat breed compared to both Sirohi and
Jhakrana breeds of goat during heat stress clearly established the breed differences in adaptation within a species (Kumar et al 2017). Similarly, in a comparative study by Ashutosh et al (2000) identified that the RR and RT are higher in Avivastra sheep than Chokla sheep breed during heat stress exposure. In another recent study, Aritonang et al (2017) compared the adaptive capacity of Bali cattle with Sumbawa Ongole cattle and observed that Bali cattle relied much on RT while Ongole cattle relied on the respiration rate to maintain the thermal balance. Further, Gir cattle breed was the breed least adapted while the Sindhi and Girolando breeds showed the best physiological response to thermal stress (Cardoso et al 2015). In another recent experiment Sailo et al (2017) reported that Sahiwal cows are less sensitive and better able to regulate body twmperature in response to heat stress than Karan Fries cows.

\section{Different physiological biomarkers for quantifying heat stress in livestock}

Heat stress causes changes in phenotypic and genotypic traits in livestock and is quantified by the measurement of physiological responses such as RR, RT, ST, PR and SR (McManus et al 2009). Among the physiological parameters RR, RT and ST are identified as the biomarkers for quantifying the heat stress impact on livestock (Shaji et al 2016). Further, RR was identified to be the ideal physiological biomarker for quantifying heat stress response in livestock (Dalcin et al 2016). Livestock especially ruminants adapt to the stressful condition through increasing the evaporative cooling mechanism by enhancing RR to reduce the extra heat load in them (Singh et al 2016). Further, the exposure of livestock to heat stress may rise the RT as a natural mechanism to dissipate extra heat load to maintain homeostasis (ElTarabany et al 2017). The increased RT implies the inability of the animal to maintain the normal body temperature during exposure to summer heat stress (Marai et al 2007). Therefore, $\mathrm{RT}$ is also considered as vital biomarker for quantifying heat stress condition in livestock. In addition to both RR and RT, ST is also identified as important biomarker for quantifying heat stress affect on livestock. The exposure of animals to hot environment increases their ST to maintain the thermal status in their body. Increased ST directly attributed to vasodilatation of skin capillary bed and increase in the blood flow to the skin surface to facilitate heat dissipation in animal (McManus et al 2009; Shilja et al 2016; Katiyatiya et al 2017). Therefore, RR, RT and ST could serve as ideal physiological biomarkers for quantifying heat stress response in livestock and these markers may be very useful in identifying thermotolerant breeds to sustain livestock production in the changing climatic scenario. 
Table 1 Breed difference in physiological adaptability of heat stressed livestock.

\begin{tabular}{|c|c|c|c|c|}
\hline Species & Breed & Level of Heat stress & Physiological adaptability & Reference \\
\hline \multirow[t]{5}{*}{ Goat } & Saanen & $\begin{array}{l}33.2^{\circ} \mathrm{C} \\
(\mathrm{THI}-82.2 \pm 1.6)\end{array}$ & $\begin{array}{l}\text { RT- } 39.11 \pm 0.31^{\circ} \mathrm{C} \\
\text { ST- } 33.75 \pm 0.99^{\circ} \mathrm{C} \\
\text { RR- } 72.93 \pm 22.69 \text { breaths/min } \\
\text { HR- } 106.70 \pm 15.27 \text { beats } / \mathrm{min}\end{array}$ & Souza et al 2014 \\
\hline & $\begin{array}{l}\text { Saanen X Anglo- } \\
\text { Nubian }\end{array}$ & $\begin{array}{l}33.2^{\circ} \mathrm{C} \\
\text { (THI- } 82.2 \pm 1.6 \text { ) }\end{array}$ & $\begin{array}{l}\text { RT- } 38.97 \pm 0.26^{\circ} \mathrm{C} \\
\text { ST- } 33.92 \pm 1.06^{\circ} \mathrm{C} \\
\text { RR- } 54.55 \pm 18.59 \text { breaths } / \mathrm{min} \\
\text { HR- } 90.07 \pm 14.27 \text { beats } / \mathrm{min}\end{array}$ & Souza et al 2014 \\
\hline & Barbari & $\begin{array}{l}44.53^{\circ} \mathrm{C} \\
\text { (THI- } 81.63 \text { ) }\end{array}$ & $\begin{array}{l}\text { RR- } 26.60 \pm 0.24 \text { breaths } / \mathrm{min} \\
\text { RT- } 38.61 \pm 0.12{ }^{\circ} \mathrm{C}\end{array}$ & Kumar et al 2017 \\
\hline & Sirohi & $\begin{array}{l}44.53^{\circ} \mathrm{C} \\
\text { (THI- } 81.63 \text { ) }\end{array}$ & $\begin{array}{l}\text { RR- } 28.80 \pm 0.58 \text { breaths } / \mathrm{min} \\
\text { RT- } 37.80 \pm 0.16^{\circ} \mathrm{C}\end{array}$ & Kumar et al 2017 \\
\hline & Jhakrana & $\begin{array}{l}44.53^{\circ} \mathrm{C} \\
(\mathrm{THI}-81.63)\end{array}$ & $\begin{array}{l}\text { RR- } 28.80 \pm 0.58 \text { breaths } / \text { min } \\
\text { RT- } 37.65 \pm 0.12^{\circ} \mathrm{C}\end{array}$ & Kumar et al 2017 \\
\hline \multirow[t]{4}{*}{ Sheep } & Santa Inês & $36.2^{\circ} \mathrm{C}$ & $\begin{array}{l}\text { RR- } 113 \pm 27 \text { breaths/min } \\
\text { HR- } 134 \pm 9 \text { beats/min } \\
\text { RT- } 39.6 \pm 0.1^{\circ} \mathrm{C}\end{array}$ & Gesualdi et al 2014 \\
\hline & $\begin{array}{l}\text { F1 Dorper } \times \text { Santa } \\
\text { Inês cross }\end{array}$ & $36.2^{\circ} \mathrm{C}$ & $\begin{array}{l}\text { RR- } 135 \pm 27 \text { breaths/min } \\
\text { HR- } 141 \pm 9 \text { beats/min } \\
\text { RT- } 39.7 \pm 0.1^{\circ} \mathrm{C}\end{array}$ & Gesualdi et al 2014 \\
\hline & Chokla & THI- $78.95 \pm 1.58$ & $\begin{array}{l}\text { RR- } 79.09 \pm 0.50 \text { breaths/minute } \\
\text { PR- } 77.94 \pm 0.29 \text { beats/min } \\
\text { RT- } 38.31 \pm 0.09{ }^{\circ} \mathrm{C}\end{array}$ & Ashutosh et al 2000 \\
\hline & Avivastra & THI- $78.95 \pm 1.58$ & $\begin{array}{l}\text { RR- } 57.14 \pm 0.50 \text { breaths/minute } \\
\text { PR- } 79.15 \pm 0.29 \text { beats/min } \\
\text { RT- } 38.26 \pm 0.09{ }^{\circ} \mathrm{C}\end{array}$ & Ashutosh et al 2000 \\
\hline \multirow[t]{9}{*}{ Cattle } & Gir & $\begin{array}{l}35.9^{\circ} \mathrm{C} \\
\text { (THI- 69.09) }\end{array}$ & $\begin{array}{l}\text { RT- } 39.05^{\circ} \mathrm{C} \\
\text { HR- } 66.82 \text { beats/min } \\
\text { RR- } 36.22 \text { breaths/min } \\
\text { ST- } 32.97{ }^{\circ} \mathrm{C}\end{array}$ & Cardoso et al 2015 \\
\hline & Girol Najdiando & $\begin{array}{l}35.9^{\circ} \mathrm{C} \\
(\mathrm{THI}-69.09)\end{array}$ & $\begin{array}{l}\text { RT- } 38.65{ }^{\circ} \mathrm{C} \\
\text { HR- } 57.91 \text { beats/min } \\
\text { RR- } 39.15 \text { breaths/min } \\
\text { ST- } 32.60{ }^{\circ} \mathrm{C}\end{array}$ & Cardoso et al 2015 \\
\hline & Nelore & $\begin{array}{l}35.9^{\circ} \mathrm{C} \\
\text { (THI- } 69.09)\end{array}$ & $\begin{array}{l}\text { RT- } 38.87^{\circ} \mathrm{C} \\
\text { HR- } 64.11 \text { beats/min } \\
\text { RR-41.00 breaths/min } \\
\text { ST-31.89 } \mathrm{C}\end{array}$ & Cardoso et al 2015 \\
\hline & Sindhi & $\begin{array}{l}35.9^{\circ} \mathrm{C} \\
\text { (THI- } 69.09)\end{array}$ & $\begin{array}{l}\text { RT- } 38.86{ }^{\circ} \mathrm{C} \\
\text { HR- } 56.53 \text { beats/min } \\
\text { RR- } 36.53 \text { breaths/min } \\
\text { ST- } 32.08{ }^{\circ} \mathrm{C}\end{array}$ & Cardoso et al 2015 \\
\hline & Indubrasil & $\begin{array}{l}35.9^{\circ} \mathrm{C} \\
\text { (THI- 69.09) }\end{array}$ & $\begin{array}{l}\text { RT-39.00 }{ }^{\circ} \mathrm{C} \\
\text { HR-61.51 beats/min } \\
\text { RR-33.75 breaths/min } \\
\text { ST-31.57 }{ }^{\circ} \mathrm{C}\end{array}$ & Cardoso et al 2015 \\
\hline & Sahiwal & $\frac{39.35 \pm 0.94^{\circ} \mathrm{C}}{(\mathrm{THI}-87.28 \pm 1.26)}$ & $\begin{array}{l}\text { RT- } 38.810 \pm 0.095{ }^{\circ} \mathrm{C} \\
\text { RR- } 29.818 \pm 0.795 \text { breaths/min }\end{array}$ & Sailo et al 2017 \\
\hline & Karan Fries & $\frac{39.35 \pm 0.94^{\circ} \mathrm{C}}{(\mathrm{THI}-87.28 \pm 1.26)}$ & $\begin{array}{l}\text { RT- } 39.186 \pm 0.115^{\circ} \mathrm{C} \\
\text { RR-47.299 } \pm 1.136 \text { breaths/min }\end{array}$ & Sailo et al 2017 \\
\hline & Angus & $\begin{array}{l}31.8 \pm 0.4^{\circ} \mathrm{C} \\
(\mathrm{THI}-81.5 \pm 1.0)\end{array}$ & $\begin{array}{l}\text { RR- } 104.0 \pm 1.83 \text { breaths } / \mathrm{min} \\
\text { ST- } 36.2 \pm 0.12^{\circ} \mathrm{C} \\
\text { HR- } 87.0 \pm 1.21 \text { beats } / \mathrm{min}\end{array}$ & Valente et al 2015 \\
\hline & Nellore bull & $\begin{array}{l}31.8 \pm 0.4{ }^{\circ} \mathrm{C} \\
(\mathrm{THI}-81.5 \pm 1.0)\end{array}$ & $\begin{array}{l}\text { RR- } 45.2 \pm 1.95 \text { breaths } / \mathrm{min} \\
\text { ST }-35.6 \pm 0.12^{\circ} \mathrm{C}\end{array}$ & Valente et al 2015 \\
\hline
\end{tabular}

RR- Respiration rate; RT- Rectal temperature; PR- Pulse rate; HR- Heart rate; ST- Skin temperature; SR- Sweating rate 


\section{Final Considerations}

This review highlights the importance of adapting livestock to the changing climate scenario. Initial emphasis was given to describe the climate change impact and in particular the effects of heat stress as the most crucial factor which negatively influences livestock production. Among the various adaptive mechanisms exhibited by the animals on exposure to adverse environmental conditions, physiological adaptability seems to be the initial adaptive pathway of the animals. Physiological responses were considered to be the immediate response by which the heat stressed animals survive the stress impacts. There are various physiological responses such as RR, RT, PR, ST and SR which promote welfare and favors survival of the animals to a specific environment. The physiological adaptive mechanisms results in yielding of appropriate phenotypic markers such as RR, RT and ST which helps to quantify the response in heat stressed livestock. Further, it was established that the physiological adaptive mechanisms varies between the species and within a species breed differences were also reported. Therefore, it may be concluded that heat stressed livestock rely heavily on the physiological response mechanisms to cope with the adverse environmental conditions and the phenotypic markers those emerge in this pathway may serve as useful indicators of animal welfare in the changing climatic condition.

\section{Acknowledgement}

The authors thank sincerely Director, NIANP for providing all necessary facilities for preparing this review article.

\section{References}

Alameen AO, Abdelatif AM (2012) Metabolic and endocrine responses of crossbred dairy cows in relation to pregnancy and season under tropical conditions. American-Eurasian Journal of Agricoltural \& Environmental Science 12:1065-1074.

Alamer M (2011) Water requirements and body water distribution in Awassi sheep and Aardi goats during winter and summer seasons. The Journal of Agricultural Science 149:227-234.

Aleena J, Pragna P, Archana PR, Sejian V, Bagath M, Krishnan G, Manimaran A, Beena V, Kurien EK, Varma G, Bhatta R (2017) Significance of Metabolic Response in Livestock for Adapting to Heat Stress Challenges. Asian Journal of Animal Science 10:9-16.

Al-Haidary AA (2004) Physiological responses of Naimey sheep to heat stress challenge under semi-arid environments. International Journal of Agriculture and Biology 2:307-309.

Al-Haidary AA, Aljumaah RS, Alshaikh MA, Abdoun KA, Samara EM, Okab AB, Alfuraiji MM (2012) Thermoregulatory and physiological responses of Najdi sheep exposed to environmental heat load prevailing in Saudi Arabia. Pakistan Veterinary Journal 32:515-519.
Amundson JL, Mader TL, Rasby RJ, Hu QS (2006) Environmental effects on pregnancy rate in beef cattle. Journal of Animal Science 84:3415-3420.

Aritonang SB, Yuniati R, Abinawanto, Imron M, Bowolaksono A (2017) Physiology Response of the Indigenous Cattle Breeds to the Environment in West Sumbawa, Indonesia. AIP Conference Proceedings 1862, 030098. doi: 10.1063/1.4991202

Ashutosh A, Dhanda O, Kunou R (2000) Physiological responses of native and crossbred sheep to climatic stress under semi-arid conditions. Indian Journal of Animal Science 8:857-861.

Aziz MA (2010) Present status of the goat populations and their productivity. Lohmann Information 45:42-52.

Berman A (2005) Estimates of heat stress relief needs for Holstein dairy cows. Journal of Animal Science 83:1377-1384.

Bhakat M, Mohanty TK, Gupta AK, Abdullah M (2014) Effect of season on semen quality of crossbred (Karan Fries) bulls. Advances in Animal and Veterinary Sciences 2:632-637.

Cardoso CC, Peripolli V, Amador SA, Brandão EG, Esteves GI, Sousa CM, França MF, Gonçalves FG, Barbosa FA, Montalvão TC, Martins CF (2015) Physiological and thermographic response to heat stress in zebu cattle. Livestock Science 182:83-92.

Chakravarthi K, Bidarkar DK, Ramesh Gupta B, Rao GN, Sudhakar K, Babu Rao K (2004) Drought performance of Ongole bulls under thermal stress conditions. Indian Journal of Animal Science 74:119121.

Chandra Bhan, Singh SV, Hooda OK, Upadhyay RC, Beenam, Mangesh V (2012) Influence of temperature variability on Physiological, hematological and biochemical Profile of growing and Adult Sahiwal cattle. Journal of Environmental Research and Development 7:986-994.

Chandra Bhan, Singh SV, Upadhyay RC, Hooda OK, Baliyan Beenam (2013) Impact of temperature variability on physiological, hematological and biochemical profile of growing and adult Murrah buffaloes. Journal of Agrometeorology 15:146-152.

da Silva RG, La Scala Jr N, Tonhati H (2003) Radiative properties of the skin and haircoat of cattle and other animals. Transactions of the ASAE 46:913.

da Silva WE, Leite JHGM, de Sousa JER, Costa WP, da Silva WST, Guilhermino MM, Façanha DAE (2017) Daily rhythmicity of the thermoregulatory responses of locally adapted Brazilian sheep in a semiarid environment. International Journal of Biometerology 61:1221-1231.

Dalcin VC, Fischer V, Daltro DD, Alfonzo EP, Stumpf MT, Kolling GJ, Silva MV, McManus C (2016) Physiological parameters for thermal stress in dairy cattle. Revista Brasileira de Zootecnia 45:458465 .

Das MR, Sarma RK, Saikia R, Kale VS, Shelke MV, Sengupta P (2011) Synthesis of silver nanoparticles in an aqueous suspension of graphene oxide sheets and its antimicrobial activity. Colloids and Surfaces B: Biointerfaces 83:16-22.

Das R, Sailo L, Verma N, Bharti P, Saikia J (2016) Impact of heat stress on health and performance of dairy animals: A review. Veterinary World 9:260.

Delgado C (2005) Rising demand for meat and milk in developing countries: implications for grasslands-based livestock production. In: McGilloway DA (Ed.) Grassland: a global resource. The Netherlands: Wageningen Academic Publishers 29-39. 
El-Tarabany MS, El-Tarabany AA, Atta MA (2017) Physiological and lactation responses of Egyptian dairy Baladi goats to natural thermal stress under subtropical environmental conditions. International Journal of Biometeorology 61:61-68.

FAO (Food and Agriculture Organization), IFAD (International Fund for Agriculture Development) and WFP (world Food Programme) (2015). The State of Food Insecurity in the World 2015. Meeting the 2015 international hunger targets: taking stock of uneven progress. Rome, FAO.

Garnett T (2009) Livestock-related greenhouse gas emissions: impacts and options for policymakers. Environmental Science \& Policy 12:491-503.

Gebremedhin KG, Hillman PE, Lee CN, Collier RJ, Willard ST, Arthington JD, Brown-Brandl TM (2008) Sweating rates of dairy cows and beef heifers in hot conditions. Transactions of the ASABE 51:2167-2178.

Gebremedhin KG, Wu B (2001) A model of evaporative cooling of wet skin surface and fur layer. Journal of Thermal Biology 26:537545 .

Gesualdi Júnior A, Sales ÉS, Freitas RS, Henry FD, Oliveira VD, Gesualdi AC (2014) Effects of heat stress on the physiological parameters and productivity of hair sheep in tropical and coastal environments. Revista Brasileira de Zootecnia 43:556-560.

Gupta M, Kumar S, Dangi SS, Jangir BL (2013) Physiological, biochemical and molecular responses to thermal stress in goats. International Journal of Livestock Research 3:27-38.

Henry B, Charmley E, Eckard R, Gaughan JB, Hegarty R (2012) Livestock production in a changing climate: adaptation and mitigation research in Australia. Crop and Pasture Science 63:191202.

Hillman PE, Gebremedhin KG, Brown-Brandl TM, Lee CN (2005) Thermal analysis and behavioral activity of heifers in shade or sunlight. In: Livestock Environment VII, Beijing, China. American Society of Agricultural and Biological Engineers. 151.

Hillman PE, Lee CN, Carpenter JR, Baek KS, Parkhurst A (2001) Impact of hair color on thermoregulation of dairy cows to direct sunlight. In: ASAE Annual Meeting 1998. American Society of Agricultural and Biological Engineers.

Hooda OK, Upadhyay RC (2014) Physiological responses, growth rate and blood metabolites under feed restriction and thermal exposure in kids. Journal of Stress Physiology \& Biochemistry. 10:214-227.

Indu S, Pareek A (2015) A Review: Growth and Physiological Adaptability of Sheep to Heat Stress under Semi-Arid Environment. International Journal of Emerging Trends in Science and Technology. doi 10.18535/ijetst/v2i9.09

IPCC (Intergovermental Panel on Climate Change) (2013) The physical science basis. In: Stocker TF, Qin D, Plattner GK, Tignor M, Allen SK, Boschung J, Nauels A, Xia Y, Bex V, Midgley PM (Eds.) Contribution of Working Group I to the Fifth Assessment Report of the Intergovernmental Panel on Climate Change. Cambridge University Press, Cambridge, United Kingdom and New York, NY, USA. 1535.

IPCC (Intergovernmental Panel on Climate Change) (2007) Fourth Assessment Report: Climate Change, Working Group I: The Physical Science Basisrect Global Warming Potentials. Solomon S, Qin D, Manning M, Chen Z, Marquis M, Averyt KB, Tignor M, Miller HL (eds.). Cambridge University Press, Cambridge, United Kingdom and New York, NY, USA, pp 996.
Jiang M, Gebremedhin KG, Albright LD (2005) Simulation of skin temperature and sensible and latent heat losses through fur layers. Transactions of the ASAE 48:767-775.

Kadzere CT, Murphy MR, Silanikove N, Maltz E (2002) Heat stress in lactating dairy cows: a review. Livestock Production Science 77:59-91.

Katiyatiya CLF, Bradley G, Muchenje V (2017) Thermotolerance, health profile and cellular expression of HSP90AB1 in Nguni and Boran cows raised on natural pastures under tropical conditions. Journal of Thermal Biology 69:85-94.

Koga A, Kuhara T, Kanai Y (2004) Comparison of body water retention during water deprivation between swamp buffaloes and Friesian cattle. Journal of Agricultural Science 138:435-440.

Koubkova, M., Kuizkova I., Kunc P., Hartlova H., Flusser Jersey, Dolezal O (2002) Influence of high environmental temperature and evaporative cooling on some physiological, haemamtological and biochemical parameters in high yielding dairy cows. Journal of Animal Science 47:309-318.

Kumar D, Yadav B, Choudhury S, Kumari P, Madan AK, Singh SP, Rout PK, Ramchandran N, Yadav S (2017) Evaluation of adaptability to different seasons in goat breeds of semi-arid region in India through differential expression pattern of heat shock protein genes. Biological Rhythm Research 15:1-3.

Kumar V, Ravikumar RK (2016) Indigenous innovations in livestock production systems: NIF initiatives. In: Invited Papers: Innovative Designs and Implements for Global Environment and Entrepreneurial Needs Optimizing Utilitarian Sources, Indigenous, International Livestock Conference and Expo, 23rd Annual Convention, ISAPM, Hyderabad, India. 28-31.

Lamy E, van Harten S, Sales-Baptista E, Guerra MM, de Almeida AM (2012) Factors influencing livestock productivity. In: Environmental stress and amelioration in livestock production. Springer Berlin Heidelberg, pp 19-51.

Mader TL (2003) Environmental stress in confined beef cattle. Journal of Animal Science 81:110-119.

Marai IF, El-Darawany AA, Fadiel A, Abdel-Hafez MA (2007) Physiological traits as affected by heat stress in sheep-a review. Small Ruminant Research 71:1-2.

Marai IF, Haeeb AA (2010) Buffalo's biological functions as affected by heat stress-A review. Livestock Science 127:89-109.

Marai IFM, Bhagat LB, Shalaby TH, Abdel-Hafez MA (2000) Fattening performances, some behavioral traits and physiological reactions of male lambs fed concentrates mixture alone with or without natural clay, under hot summer of Egyptian. Annals of Arid Zone 39:449-460.

McManus CM, Paludo GR, Louvandini H, Gugel R, Sasaki LCB, Paiva SR (2009) Heat tolerance in Brazilian sheep: physiological and blood parameters. Tropical Animal Health Production 41:95-101.

Nardone A, Ronchi B, Lacetera N, Ranieri MS, Bernabucci U (2010) Effects of climate change on animal production and sustainability of livestock systems. Livestock Science 130:57-69.

Nienaber JA, Hahn GL (2007) Livestock production system management responses to thermal challenges. International Journal of Biometeorology 52:149-157.

Nwosu CC, Ogbu CC. 2011. Climate change and livestock production in nigeria: issues and concerns. Agro-Science J Trop Agri, Food, Environ Extension 10:41-60. 
Paulo JLA, Lopes FA (2014) Daily activity patterns of Saanen goats in the semi-arid northeast of Brazil. Revista Brasileira de Zootecnia 43:464-470.

Popoola MA, Bolarinwa MO, Yahaya MO, Adebisi GL, Saka AA (2014) Thermal comfort effects on physiological adaptations and growth performance of West African dwarf goats raised in Nigeria. European Scientific Journal 10:275-281.

Pragnna P, Sejian V, Soren NM, Bagath M, Krishnan G, Beena V, Indira Devi P, Bhatta R (2017) Summer season induced rhythmic alterations in metabolic activities to adapt to heat stress in three indigenous (Osmanabadi, Malabari and Salem Black) goat breeds. Biological Rhythm Research. doi 10.1080/09291016.2017.1386891

Renaudeau D, Huc E, Noblet J (2007) Acclimation to high ambient temperature in Large White and Caribbean Creole growing pigs. Journal of Animal Science 85:779-790.

Reynolds C, Crompton L, Mills J (2010) Livestock and climate change impacts in the developing world. Outlook Agriculture 39:245-248.

Rosegrant MW, Fernandez M, Sinha A (2009) Looking into the future for agriculture and AKST. In: McIntyre BD, Herren HR, Wakhungu J, Watson RT (Ed), International Assessment of Agricultural Knowledge, Science and Technology for Development (IAASTD). Agriculture at a crossroads, Island Press, Washington, DC, pp 307-376.

Sailo L, Gupta ID, Das R, Chaudhari MV (2017) Physiological Response to Thermal Stress in Sahiwal and Karan Fries Cows. International Journal of Livestock Research 7:275-83.

Sejian V, Maurya VP, Naqvi SM (2010) Adaptability and growth of Malpura ewes subjected to thermal and nutritional stress. Tropical Animal Health and Production 42:1763-1770.

Shaji S, Sejian V, Bagath M, Mech A, David ICG, Kurien EK, Varma G, Bhatta R (2016) Adaptive capability as indicated by behavioral and physiological responses, plasma HSP70 level and PBMC HSP70 mRNA expression in Osmanabadi goats subjected to combined (heat and nutritional) stressors. International Journal of Biometeorology 60:1311-1323.

Sharma R, Singh PK, Maitra A, Pandey AK, Mukesh M, Singh SR, Singh B (2013) Molecular characterization, body parameters and management practices of Purnea cattle. Indian Journal of Animal Science 83:536-541.

Silanikove N, Koluman N (2015) Impact of climate change on the dairy industry in temperate zones: predications on the overall negative impact and on the positive role of dairy goats in adaptation to earth warming. Small Ruminant Research 123:27-34.

Singh KM, Singh S, Ganguly I, Ganguly A, Nachiappan RK, Chopra A, Narula HK (2016) Evaluation of Indian sheep breeds of arid zone under heat stress condition. Small Ruminant Research 141:113-117.

Singh R, Singh SV (2005) Variations in cutaneous temperature, physiological responses and blood biochemical in Karan Fries and Sahiwal heifers during solar exposure in summer. Indian Journal of Dairy Science 58:415-419.

Souza PT, Salles MG, da Costa AN, Carneiro HA, de Souza LP, Rondina D, de Araújo AA (2014) Physiological and production response of dairy goats bred in a tropical climate. International Journal of Biometeorology 58:1559-1567.

Sprott LR, Selk GE, Adams DC (2001) Factors affecting decisions on when to calve beef females. The Professional Animal Scientist $17: 238-246$.
Steinfeld H, Gerber P, Wassenaar TD, Castel V, de Haan C (2006) Livestock's long shadow: environmental issues and options. Food \& Agriculture Organisation.

Svotwa E, Makarau A, Hamudikuwanda H (2007) Heat tolerance of Mashona, Brahman and Simmental cattle breeds under warm humid summer conditions of natural region II area of ZImbabew. Electronic Journal of Environmental, Agricultural and Food Chemistry 6:1934 $-1944$.

Thornton PK (2010) Livestock production: recent trends, future prospects. Philosophical Transactions of the Royal Society of London B: Biological Sciences 365:2853-2867.

UNPD (United Nations Population Division) (2008) World population prospects: the 2006 revision. UNPD. http://esa.un.org/unpp/.

Upadhyay RC, Sirohi S, Ashutosh, Singh SV, Kumar A, Gupta SK (2009) Impact of climate change on milk production in India. In: Aggarwal PK (Ed.) Global climate change and Indian agriculture, Published by ICAR, New Delhi, pp 104-106.

Valente ÉE, Chizzotti ML, de Oliveira CV, Galvão MC, Domingues SS, de Castro Rodrigues A, Ladeira MM (2015) Intake, physiological parameters and behavior of Angus and Nellore bulls subjected to heat stress. Semina: Ciências Agrárias 16:4565-4574.

van Vuuren D, Ochola W, Riha S, Giampietro M, Ginzo H, Henrichs T, Hussain SH, Kok K, Makhura MM, Mirza M, Palanisami KP (2009). Outlook on agricultural changes and its drivers. InAgriculture at a Crossroads-the Global Report of the International Assessment of Agricultural Knowledge, Science, and Technology. Island Press, pp 255-305

Walker B, Carpenter S, Anderies J, Abel N, Cumming G, Janssen M, Lebel L, Norberg J, Peterson G, Pritchard R (2002) Resilience management in social-ecological systems: a working hypothesis for a participatory approach. Conservation ecology. 19. URL: http://www.consecol.org/vol6/iss1/art14

World Bank (2009) Minding the stock: bringing public policy to beasssr on livestock sector development. Washington, Report no. 44010-GLB. 